DOI: 10.20472/EFC.2019.012.020

\author{
NASIR SELIMI \\ South East European University, Macedonia \\ MURAT SADIKU \\ South East European University, Macedonia \\ LULJETA SADIKU \\ International Balkan University, Macedonia
}

\title{
WHY EXPORT IS HOPE FOR ECONOMIC GROWTH FOR NORTH MACEDONIA
}

\begin{abstract}
:
The development of international trade today represents one of the priorities of the world economies. Scientific studies dealing with the relationship between foreign trade and economic development are numerous and with no doubt increase the interest among the readers. As a result, researchers make a variety of analyzes and conclusions that presents valuable contributions to the science of economics. North Macedonia in its macroeconomic policy as a priority enlist the development of international trade. However, the trade balance in 2018 year revealed the existing problem of trade deficit, as again reached a very high percentage. This is a signal that warns the country's economy in the present and in the future.

The causes of this situation are various, but some are more fundamental. As one of the most was undoubtedly the global financial and economic crisis that were present especially in the European Union member countries. Countries being in this situation, reduced the demand for goods from the different companies from North Macedonia. But this is not the only reason for the difficult position of North Macedonia. Another unfavorable condition is the economic structure of the North Macedonian economy which perhaps is the most important reason. To get out of this situation, North Macedonia in the future must change its economic structure and should be oriented in producing goods that are required more in the global market. It cannot hope to compete in the world market with the goods that competes nowadays in order to be able to improve the balance of foreign trade.
\end{abstract}

\section{Keywords:}

Export, import, trade balance, deficit, surplus.

JEL Classification: F10, F43, L60 


\section{Introduction}

The development of international trade today represents with no doubt one of the priorities of the world economies. Countries have paid a special attention and dedicated themselves to this important factor for economic development since ancient time. It is no coincidence that countries, who have been leaders in economic and social development, also have been the leaders of world trade. Even today, the U.S. Germany, USA, Japan, as major economic forces in the world, rank themselves as the world leaders in terms of their participation in the global trade. China, India and other developing countries are increasing their presence in the world market. Scientific studies dealing with the relationship between foreign trade and economic development are numerous and with no doubt increase the interest among the readers. Thus, researchers make a variety of analyzes and conclusions that presents valuable contributions to the science of economics. The scientific study of two professors from the University of Harvard, Sachs and Warner (1995) show that developing countries during the `70 and 80 opened their markets to the world, and had an average economic gain of $4.5 \%$, whereas closed economies only $0.7 \%$. They also stated that developed countries with open economies have an economic growth of $2.3 \%$, while those countries with closed economies had only $0.7 \%$ of economic growth. A same conclusion was reached in a scientific study in 2003 carried by economists Wacziarg and Horn Welch. It is a fact that most economists are for developing international trade. The majority of economists support the open economy and foreign trade development considering the benefits gained from it compared to the damage that may have them. The following are to be found as the biggest benefits that come from open economies: more supplies of goods, goods and services with higher quality offered to customers, increased welfare, technology development, increased research and scientific research, etc.

Some economists such as (Krueger, 1998); (Tyler, 1981); (Balassa, 1985); (Ram, 1985); (Feder, 1982); argued that export positively affect the economic growth, some others such as (Kwan \& Cotsomitis, 1990); (Ahmad \& Kwan, 1991); (Yagmaian, 1994) came up with counter-arguments to export-led growth. The empirical results provided by the study of (Vohra, 2001) also revealed that exports have a positive and significant impact on economic growth when a country achieved some level of economic development.

North Macedonia in its macroeconomic policy as a priority enlist the development of international trade. The role and its importance of international trade development was emphasized with the moment of becoming a member of World Trade Organization in 2003. The process of membership brought the country many benefits, but also obliged the country with duties and regulations to follow and obey them. When the questions of the volume of benefits that arise from the point of an open economy, many scientist, administrators and other interested parties are curious about its benefits compared to possible damages. It is clear that the benefits of member states overcome the damages, otherwise countries would not show interest in WTO membership.

Even with the case of North Macedonia, there are claims that support the theory of protectionism, but the majority are for the idea that the open economy and international trade liberalization it is a must. From its membership in this organization the economic growth and trade balance increased 
in a yearly basis noticeably. The increase in exchange trade with other countries impacts positively the development of the economy and business in general.

\section{Exporting Goods of North Macedonia}

The Republic of North Macedonia during the year 2018 made an exchange trade of 15.960 million US dollars. This exchange compared to that of the year of 2017 shows an increase of $19.2 \%$. The export part in the exchange trade structure of the year 2018 is $43.0 \%$, whereas in 2017 was $42.3 \%$. On the other hand, the import in the overall structure of trade exchange shows a slight decrease of $0.6 \%$. In 2017, the import represented $57.6 \%$ of trade exchange, whereas in 2018 it is $57.0 \%$. A such trade balance of foreign exchange trade where export constitutes only one third of the exchange make us aware that the trade is not favorable, even though this year it has a slight improvement. The export coverage of import in this analyzed year is $76.3 \%$, which compared with the last year of $73.4 \%$ shows an increase of $2.9 \%$. In the last five years, there are some companies including Johnson Matthey, Johnson Controls, Van Hool, Key Safety Systems, DraexImaier, and Kromberg \& Schubert who contributed on export growth. These companies have since 2011 created an estimated 18,000 jobs, about 23 percent of all new jobs, of which one-third are skilled and two-thirds low-skilled (the latter are concentrated in two companies that produce wire harnessing).

Table 1: External Trade Scope of the Republic of Macedonia, 2018 (in million USD)

\begin{tabular}{|c|c|c|c|}
\hline & \multicolumn{2}{|c|}{ Amount in 000 USD } & Index \\
\hline & 2017 & 2018 & $2018 / 2017$ \\
\hline Trade volume & 13.391 & 15.960 & 119.2 \\
\hline Export & 5.691 & 6.908 & 121.8 \\
\hline Import & 7.720 & 9.052 & 117.3 \\
\hline Trade deficit & 2.049 & 2,144 & 104.6 \\
\hline Covering import with export \% & 73.4 & 76.3 & 103.9 \\
\hline
\end{tabular}

Source: State Statistical Office of North Macedonia, Skopje, 2019

Facts show that North Macedonia still in 2018 had a high trade deficit with an amount of 2.144 million US dollars. The trade deficit of the year 2018 compared to the trade deficit of the previous year that was 2.049 million US dollars, notes an increase of $4.6 \%$. The trade deficit of the year 2018 represents $13.4 \%$ of the total exchange, but in the year 2017 the same indicator reached the amount of 2.049 and contained $15.3 \%$ of the total exchange. From the above facts it can be noticed that the trade deficit part in trade Exchange in year 2018 shows an increase of 1.9 points which is a negative sign.

The export in the year 2018 reached an amount of 6.908 million US dollars, whereas the import in the same year was 9.052 million US dollars. Import coverage with export is $76.3 \%$. The goods export participates on GDP of North Macedonia in 2018 was 42.7\%, which is more compare with 2017 for $2.3 \%$ also bigger for $12.9 \%$ than the average of WB6. 


\subsection{Export Activities According to Types of Goods}

In 2018 Macedonia had a total export of U.S. \$ 6.908 million. This compared with a year ago marks an increase of $21.8 \%$. Firms from Macedonia during 2018 mostly exported: chemical products, animal and vegetable oils, iron and steel products, ferronickel, tobacco, beverage, textile products, processed oil and car and transport equipments. This year an export is still low. The main causes of this situation are: the unfavorable structure of the export that Macedonia has, the global economic crisis and the reduced demand for products in international market. The following table provides the structure which reflects the export of Macedonia in 2018 and its performance index compared with the previous year.

Table 2: The Export in North Macedonia according to Types of Goods in 2017/2018 (US million dollars)

\begin{tabular}{|l|r|r|r|r|}
\hline Sectors & \multicolumn{2}{|c|}{ Export } & \multicolumn{1}{l|}{ Index } & Structure \\
\hline & $\mathbf{2 0 1 7}$ & $\mathbf{2 0 1 8}$ & $\mathbf{2 0 1 7 / 2 0 1 8}$ & $\mathbf{2 0 1 8}$ \\
\hline TOTAL: & & & & \\
\hline Food products & $\mathbf{5 . 6 7 1}$ & $\mathbf{6 . 9 0 8}$ & $\mathbf{1 2 1 . 8}$ & $\mathbf{1 0 0 . 0}$ \\
\hline Beverages and tobacco & 347 & 376 & 108.4 & 5.4 \\
\hline Crude materials except fuels & 225 & 228 & 101.3 & 3.3 \\
\hline Mineral fuels, lubri. and related materials & 323 & 375 & 115.9 & 5.4 \\
\hline Animals and vegetables oils and fats & 85 & 117 & 137.2 & 1.7 \\
\hline Chemicals and products & 7 & 10 & 143,1 & 0.1 \\
\hline Manuf.goods classified mainly by materi. & 1.359 & 1.673 & 123.1 & 24.2 \\
\hline Machinery and transport equipment & 764 & 968 & 126.8 & 14.0 \\
\hline Miscellanius manufactured articles & 883 & 9.672 & 131.2 & 31.7 \\
\hline Special transactions and commodities n.s & 5 & 6 & 129.7 & 13.9 \\
\hline
\end{tabular}

Source: State Statistical Office of Macedonia, Skopje, 2019

The above-mentioned table shows the structure of exports of goods of North Macedonia in 2018, there are not any major changes compared to previous year. Thus, machinery and transport equipment participate with $31.7 \%$ in the overall export. Next, there are chemical and products with $24.2 \%$, manufacture goods with 14.0 , miscellaneous manufactured articles $13.9 \%$, food products with $5.4 \%$, etc. This structure of products that Macedonia exports are not suitable because of their additional value is not great and their prices are very sensitive on the occurrence of any crisis in the foreign market. We can notice also from the same table that exports in 2018 increased in most types of goods exported. The highest increase of export in 2018 was recorded in the group of machinery and transport equipment by $31.2 \%$, mineral fuels, lubrication and related materials by $37.2 \%$, food products by $8.4 \%$, companies compared with a year ago has exported more of this group of products with 199 million dollars. Although a greater increase of 
export may be justified to the emergence of the global economic crisis, yet this level of exports in North Macedonia has deeper roots. Macedonian products gradually lose its markets with products from other countries due to the loss of competitiveness in the global market.

Figure: 1. Export in North Macedonia According to Types of Goods, 2018

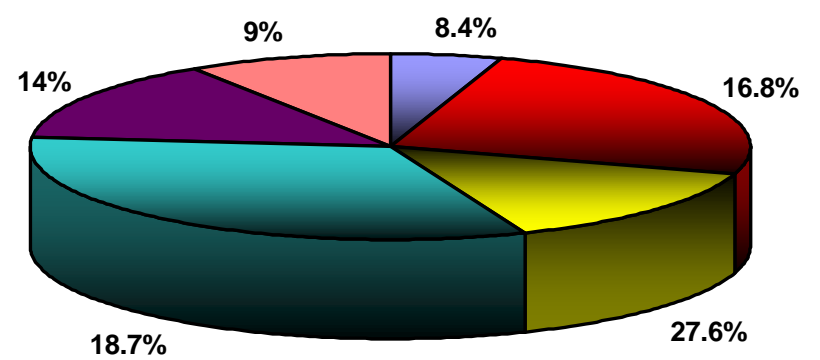

\author{
$\square$ Food product \\ $\square$ Chemical products \\ $\square$ Machinery \\ Miscellanius articles \\ 口Others
}

\title{
2.2. The Export of North Macedonian Goods by Region
}

In 2018 over half of North Macedonian export was carried out in the EU 27 member states $(82.1 \%)$. The rest was exported $(11.1 \%)$ in the Western Balkan countries, developing countries $(4.8 \%)$ and other developed countries (1.2\%). However, this export does not change a lot in the total volume of export of the country, because the share of exports to these countries is very small and irrelevant. North Macedonia's exports increase by $23.3 \%$ with EU member countries compared with a year ago. This fact encourages for a greater increase in the future, especially when we consider the participation of large exports of these countries in general structure of the Macedonian export. The export increase in 2018 was also marked with the countries of the Western Balkan (14.1\%). The export has marked positive results with developing countries and has increased by $43.8 \%$.

Table 3: Macedonian Export Based on Regions 2017/2018 (in milion USD)

\begin{tabular}{|l|c|c|c|c|}
\hline Countries & \multicolumn{2}{|c|}{ Export } & Index & Structure \\
\hline & $\mathbf{2 0 1 7}$ & $\mathbf{2 0 1 8}$ & $\mathbf{2 0 1 8 / 2 0 1 7}$ & $\mathbf{2 0 1 8}$ \\
\hline TOTAL: & 5.671 & 6.908 & 121.8 & 100.0 \\
\hline Developed countries & 4.772 & 5.813 & 121.8 & 84.1 \\
\hline EU countries 28 & 4.599 & 5.670 & 123.3 & 82.1 \\
\hline EFTA & 38 & 50 & 131.1 & 0.7 \\
\hline Other developed countries & 121 & 84 & 69.5 & 1.2 \\
\hline Non developed countries & 14 & 9 & 64.3 & 0.1 \\
\hline Developing countries & 233 & 335 & 143.8 & 4.8 \\
\hline Western Balkan countries & $\mathbf{6 6 6}$ & $\mathbf{7 6 0}$ & $\mathbf{1 1 4 . 1}$ & $\mathbf{1 1 . 1}$ \\
\hline
\end{tabular}

Source: State Statistical Office of North Macedonia, Skopje, 2019

If we look at table and the graph below, we will notice that the countries that Macedonia has mostly conducted trade in 2018 were: Germany, where exported goods worth of USD 3.240 
million. This general structure of the North Macedonian export represents $47.0 \%$ of total exports. The second partner of North Macedonia regarding its export in 2018 is Bulgaria. North Macedonian companies exported goods in Bulgaria at a total value of USD 361 million or $5.2 \%$ of total exports realized. The third important partner of North Macedonia is Serbia where exported goods worth of USD 277 million or $4.0 \%$ of total export. The forth export partner is Kosovo by 266 million USD. This huge amount of export realized with Kosovo makes the country to have better coverage of imports with exports reaching approximately $77.9 \%$. Kosovo represents the best market for the country. There are few countries with which North Macedonia has trade surplus, and worth mentioning: Germany (24.6\%) and Spain (13.1\%). The decrease in exports from the last year continues also with other countries that were Macedonia's key partners such as: Greece, Italy and Bulgaria. In 2018, Macedonia has exported nearly $58 \%$ of goods in these five countries. Loss of market share in these countries is worrying for the country. There are various reasons for this, but we should not underestimate the competition from other countries and losing market share in these countries. In 2018, some excellent results were achieved in exporting goods to the market in Germany. Goods were exported worth of 3.240 million USD. This amount in the overall export structure of Macedonia comprises $47.0 \%$ and is ranked the first country.

Figure 2: Exports of North Macedonia according to Regions in 2018

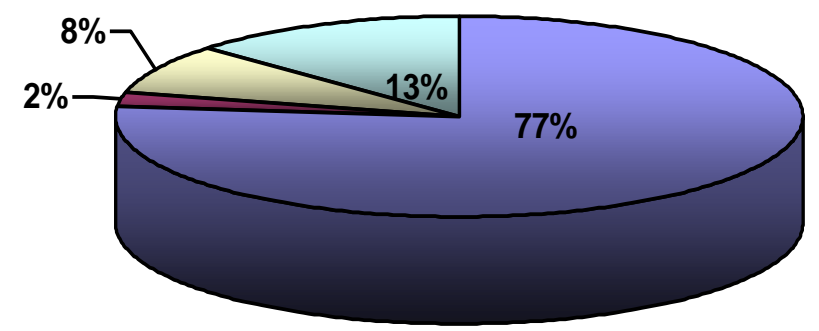

DEU countries

口Other developed countries

口Developping countries

$\square$ WB countries

Source: State Statistical Office of North Macedonia, Skopje, 2018

Table 4: Macedonian Export Based on Regions 2017/2018 (in million USD)

\begin{tabular}{|l|r|r|r|r|}
\hline \multirow{2}{*}{ Countries } & \multicolumn{2}{|c|}{ Export } & \multicolumn{1}{c|}{ Index } & \multicolumn{1}{c|}{ Structure } \\
\cline { 2 - 5 } & 2017 & 2018 & $2017 / 2018$ & \multicolumn{1}{c|}{2018} \\
\hline TOTAL & $\mathbf{5 . 6 7 1}$ & $\mathbf{6 . 9 0 8}$ & $\mathbf{1 2 1 . 8}$ & $\mathbf{1 0 0 . 0}$ \\
\hline Germany & 2.662 & 3.248 & 122.0 & 47.0 \\
\hline Serbia & 249 & 277 & 111.3 & 4.0 \\
\hline Greece & 203 & 225 & 110.1 & 3.2 \\
\hline Italy & 185 & 217 & 117.2 & 3.1 \\
\hline
\end{tabular}




\begin{tabular}{|l|r|r|r|r|}
\hline Belgium & 200 & 259 & 129.2 & 3.7 \\
\hline Bulgaria & 333 & 361 & 108.4 & 5.2 \\
\hline Kosovo & 225 & 266 & 117.8 & 3.7 \\
\hline Hungary & 85 & 142 & 165.3 & 2.0 \\
\hline Turkey & 89 & 96 & 108.4 & 1.7 \\
\hline China & 62 & 65 & 104.8 & 0.9 \\
\hline Slovenia & 76 & 92 & 120.3 & 1.6 \\
\hline Romania & 176 & 194 & 110.7 & 2.9 \\
\hline Holland & 78 & 101 & 128.7 & 1.2 \\
\hline Spain & 107 & 117 & 108.5 & 1.7 \\
\hline Great Britain & 77 & 121 & 157.9 & 1.8 \\
\hline USA & 55 & 67 & 121.3 & 0.9 \\
\hline Czech Republic & 61 & 78 & 127.9 & 1.1 \\
\hline Austria & 71 & 39 & 233.2 & 2.4 \\
\hline France & 38 & 166 & 102.3 & 0.5 \\
\hline
\end{tabular}

Source: State Statistical Office of North Macedonia, Skopje, 2019

Figure 3: Countries with the highest volume of export with North Macedonia, 2018

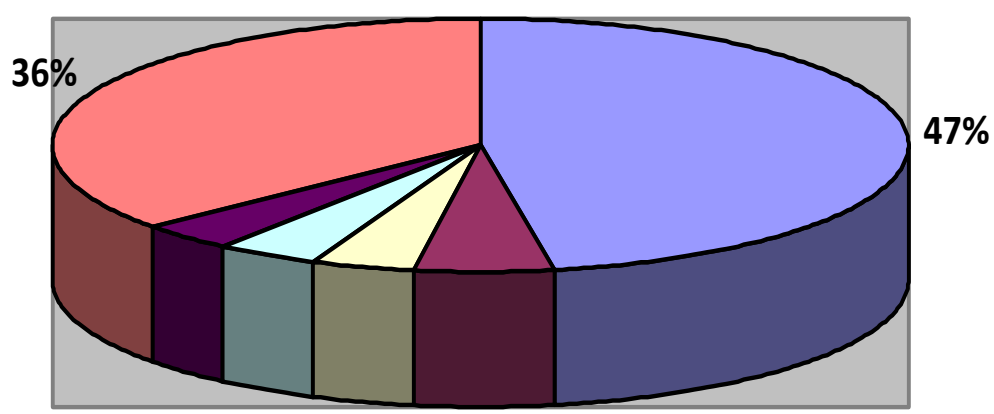

\begin{tabular}{|l}
$\square$ Germany \\
$\square$ Bulgaria \\
$\square$ Serbia \\
$\square$ Kosovo \\
$\square$ Belgium \\
$\square$ Others
\end{tabular}

Source: State Statistical Office of North Macedonia, Skopje, 2019 


\section{Regression Analysis}

The effects of exports on economic growth of North Macedonia are analyzed by a model specification estimated by OLS method, in view of the time series stationary properties. The quarterly data are used in the empirical analysis, covering the period 1999Q1-2018Q4. The main sources of data are the National Bank (NBRM) and the State Statistical Office (SSO) of North Macedonia. All the used series previously are adjusted for the effect of seasonality using ARIMA X12.

Real GDP with constant prices is taken as dependent variable, as representative of economic growth, and real exports are considered as independent variable.

Concerning the results of the regression model reveal that exports are a significant determinant of the economic growth of the country, as the coefficient is with positive sign and highly significant (see the results in the equation below). The estimated coefficient of export shows that for $1 \%$ increase of exports the real GDP will increase by $0.47 \%$, holding the other factors unchanged.$$
\Delta \ln R G D P_{i}=3.3211+0.4744 \Delta \ln E X P_{i}
$$$$
t \text { statistics (4.22) (6.13) }
$$

Likewise, the results of the model disclose a very high goodness of fit from the model's predictions and actual values (see Figure 4 below).

Figure 4. The relationship between Real Exports and Real GDP in a scattered plot graph

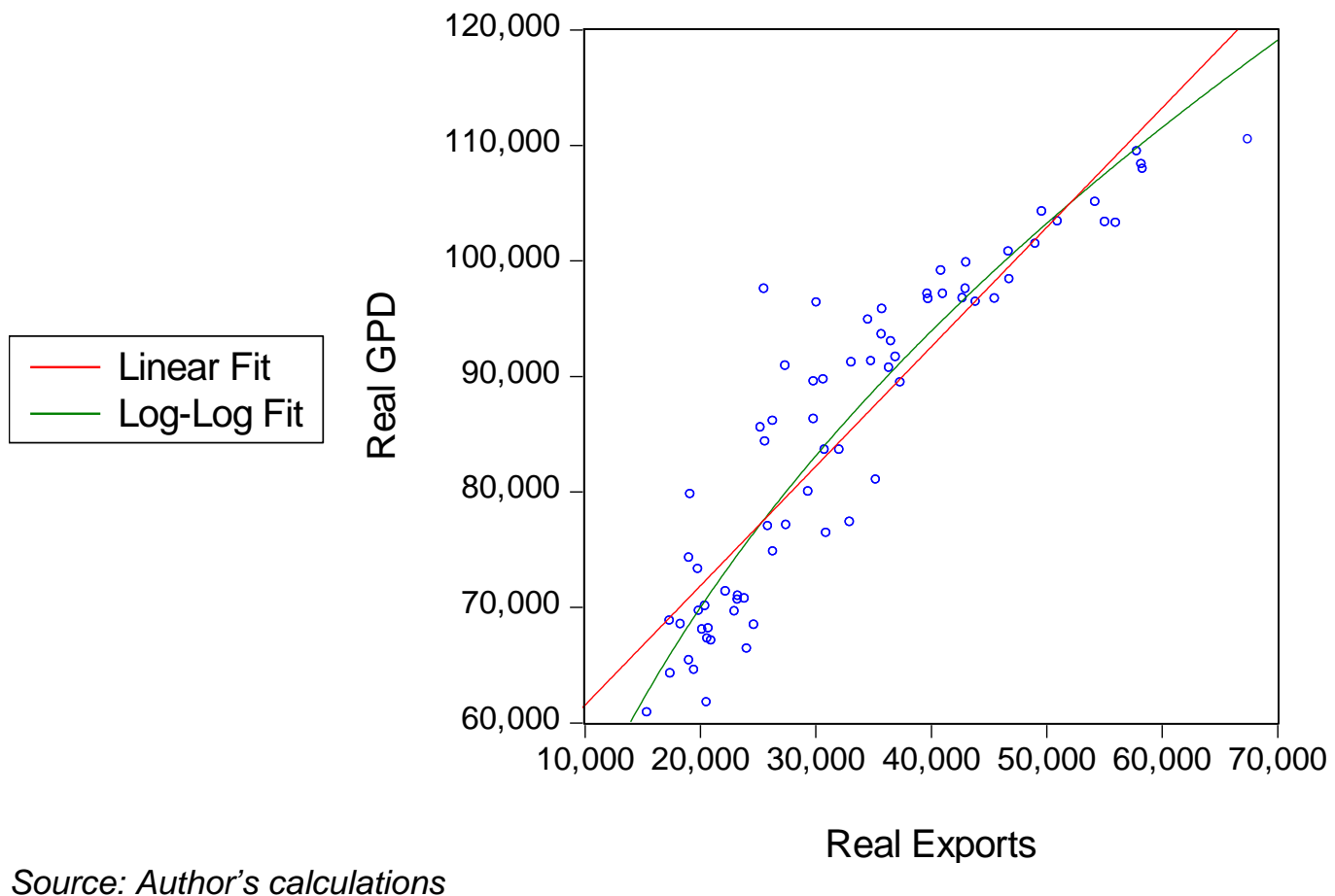




\section{Conclusion}

Macedonia during the year 2018 marked positive results in goods export. After a decline of export in 2017, North Macedonia showed an increase in export of goods. However, in 2018-year trade deficit again reached a very high percentage. This is a signal that warns the country's economy in the present and in the future.

The causes of this situation are various, but some are more fundamental. As one of the most was undoubtedly the global financial and economic crisis that were present especially in the European Union member countries. Countries being in this situation, reduced the demand for goods. But this is not the only reason for the difficult position of North Macedonia. Another unfavorable condition is the economic structure of the North Macedonian economy which perhaps is the most important reason. This is emphasized because North Macedonia had identical condition in the past years. North Macedonia's economy still competes in the international market with goods whose added value is low and in case of occurrence of crises in the world market they suffer more than other goods. To get out of this situation, Macedonia in the future must change its economic structure and should be oriented in producing goods that are required more in the global market. It cannot hope to compete in in the world market with the goods that competes today to be able to improve the balance of foreign trade.

Another factor which has a significant impact on the development of North Macedonia's foreign trade is the quality of products of country companies. The managers must follow the development of science and technology and apply that in the industry. Domestic products should meet the criteria required by international standards. They should improve the functionality and performance of customer requests. Improving the quality and design of local products will enable to be competitive with other products in the global market.

The regression results indicate a strong relationship between exports and economic growth for the case of North Macedonia, implying that the exports are a hope and an important determinant for the economic development of the country. Thus, for expanding the exports and penetrating new markets, managers of companies along with state representatives should be more determined in finding new markets for their products. Keeping and retaining current markets should be one of the concerns of managers of firms who trade on foreign markets. The next challenge should be to increase the number of firms that develop their activities abroad, while the state should stimulate them and provide favorable conditions to these firms. In this regard the contribution of the state authorities, various associations, organization of fairs in the country with an international character, the participation of businessmen in trade fairs abroad and the use of advertising and promotions is undeniable. 


\section{References}

AHMAD, J. and KWAN, A.C. (1991), "Causality between Exports and Economic Growth"; Economic Letters 37: 243-248.

BALASSA, B. (1985). "Exports, policy choices, and economic growth in developing countries after the 1973 oil shock". Journal of Development Economics 18(1),23-35.

FEDER, G. (1982), "On Exports and Economic Growth"; Journal of Development Economics 12:59-73.

KRUEGER. A. (1998). "Why Trade Liberalization is Good for Growth" (Vol. 108). The Economic Journal.

KWAN, A. and C. COTSOMITIS (1990), "Economic Growth and the Expanding Export Sector: China 1952-1985," International Economic Journal, 5: 105-116.

RAM, R., (1985) "Exports and Economic Growth: Some Additional Evidence", Economic Development and Cultural Change, 33, $415-425$.

TYLER, W. G. (1981). "Growth and export expansion in developing countries: Some empirical evidence", Journal of Development Economics Volume 9, Issue 1, Pages 121-130

SACHS \& WARNER (1995), Economic Reform and the Process of Global Integration, Washington, D.C.

YAGMAIAN, B., (1994) "An Empirical Investigation of Exports, Development and Growth in Developing Countries: Challenging the Neo-Classical Theory of Export led Growth", World Development, 22, 1977-1995

VOHRA, R. (2001). "Export and economic growth: Further time series evidence from less developed countries". International Advances in Economic Research 7.

World Bank Group, Western Balkans Regular Economic Report, No.14, Higer But Fragile Growth, Fall 2018

Investment Reform Index 2019, OECD

State Statistical Office of North Macedonia, Skopje, 2018

State Statistical Office of North Macedonia, Skopje, 2019

OECD Economic Globalization Indicators - Measuring Globalization 